PRODUCTION

ENGINEERING ARCHIVES
2015, Vol. 6, No. 1, pp. 17-20

ISSN 2353-5156

ISSN 2353-7779 (print version)

(online version)

\title{
Change of internal friction on aluminium alloy EN AC 51200 depending on temperature
}

\author{
Milan Uhríčik ${ }^{1}$, Zuzana Dresslerová ${ }^{2}$, Andrea Soviarová ${ }^{3}$, Peter Palček ${ }^{4}$ \\ ${ }^{1}$ Department of Material Engineering, Faculty of Mechanical Engineering, University of Žilina, Univerzitná 8215/1, 010 26 Žilina, Slovakia \\ (phone: 0042141513 2626, email: milan.uhricik@fstroj.uniza.sk) \\ ${ }^{2}$ Department of Material Engineering, Faculty of Mechanical Engineering, University of Žilina, Univerzitná 8215/1, 010 26 Žilina, Slovakia \\ (phone: 0042141513 2632, email: zuzana.dresslerova@fstroj.uniza.sk) \\ ${ }^{3}$ Department of Material Engineering, Faculty of Mechanical Engineering, University of Žilina, Univerzitná 8215/1, 010 26 Žilina, Slovakia \\ (phone: 0042141513 2632, email: andrea.soviarova@fstroj.uniza.sk) \\ ${ }^{4}$ Department of Material Engineering, Faculty of Mechanical Engineering, University of Žilina, Univerzitná 8215/1, 010 26 Žilina, Slovakia \\ (phone: 0042141513 2609, email: peter.palcek@fstroj.uniza.sk)
}

\begin{abstract}
The article is focused on the analysis of changes in the dependence on temperature on the aluminium alloy EN AC 51200 (10,1\% $\mathrm{Mg}, 1,32 \% \mathrm{Si}$ and $0,43 \% \mathrm{Mn}$ ) by internal friction. Internal friction is a property of the material measured on the ultrasonic resonant apparatus at a frequency of about $\mathrm{f}=20470 \mathrm{~Hz}$. The measured temperature range was from $50{ }^{\circ} \mathrm{C}$ up to $420^{\circ} \mathrm{C}$. The precise measurement of the internal friction can be monitored on an ongoing process by structural changes and various mechanisms that prevent these changes.
\end{abstract}

Key words - aluminium alloy, resonant frequency, internal friction, temperature

\section{Introduction}

The effect of a gradual storage of mechanical energy in the material results in a change of mechanical and physical characteristics, which can cause degradation of material properties such as: reduction of the machine tools accuracy, initiation of fatigue cracks, generation of noise and vibration in the working environment, changes of material properties, reduction of corrosion resistance, degradation of regulatory devices and sensors, eventually damaging the entire device. Measurement of the internal friction allows the moni- toring of the ongoing structural changes and various mechanisms (BLANTER M., 2007; PUŠKÁR A., 1995).

Aluminium is the world's most abundant metal and is the third most common element, comprising $8 \%$ of the earth's crust. The versatility of aluminium makes it the most widely used metal after steel. Pure aluminium is soft, ductile, corrosion resistant and has a high electrical conductivity. It is widely used for foil and conductor cables, but alloying with other elements is necessary to provide the higher strengths needed for other applications. Aluminium is one of the lightest engineering metals, having a strength to weight ratio 
superior to steel. By utilising various combinations of its advantageous properties such as strength, lightness, corrosion resistance, recyclability and formability, aluminium is being employed in an ever-increasing number of applications. This array of products ranges from structural materials through to thin packaging foils (www.aalco.co.uk; HURTALOVÁ L., 2013).

\section{Experimental material}

As experimental material aluminium alloy EN AC 51200 was used, which was manufactured by squeeze casting. Result of the spectrometer chemical analysis is shown in the table 1.

Table 1 Chemical composition of aluminium alloy EN AC 51200

\begin{tabular}{|c|c|}
\hline Element & [wt. \%.] \\
\hline $\mathbf{F e}$ & 0.1 \\
\hline $\mathbf{S i}$ & 1.32 \\
\hline $\mathbf{T i}$ & 0.008 \\
\hline $\mathbf{Z n}$ & 0.006 \\
\hline $\mathbf{C u}$ & 0.003 \\
\hline $\mathbf{M n}$ & 0.43 \\
\hline $\mathbf{M g}$ & 10.1 \\
\hline $\mathbf{A l}$ & balance \\
\hline
\end{tabular}

\section{Experimental equipment}

The experimental equipment, used at Department of Materials Engineering, University of Žilina, consists of mechanical and electronic parts. The mechanical part consists of three basic parts (SOVIAROVÁ A., 2013a; HLAVÁČOVÁ I., 2013):

1. From the transducer, which serves like the source and at the same time like the detector of ultrasonic waves.

2. Of the Rod, which is made of titanium and has a cylindrical shape with a diameter of $12 \mathrm{~mm}$. Its function is to isolate the heat from the test specimen, which is heated in a furnace and the transducer then maintains a constant room temperature.
3. The last part of device is the specimen (Fig. 1 and Fig. 2). Dimensions and shape of the test specimen are designed to fulfil the resonance condition, that means the natural frequency must be approximately the same like the frequency of the test equipment $\pm 10 \mathrm{~Hz}$.

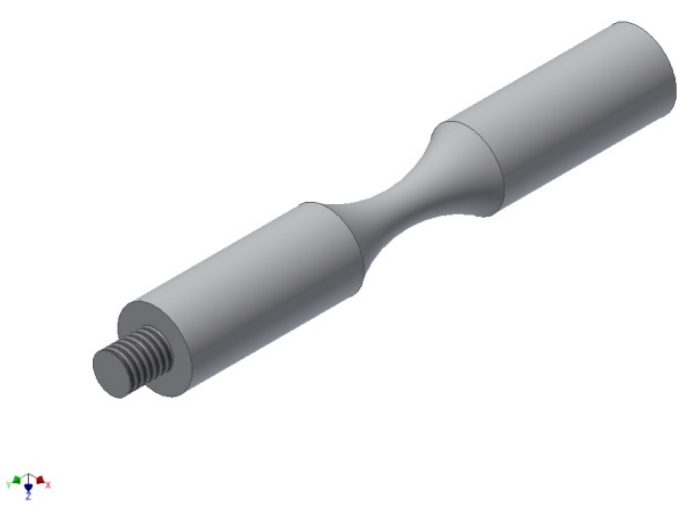

Fig. 1. Specimen for measurement internal friction

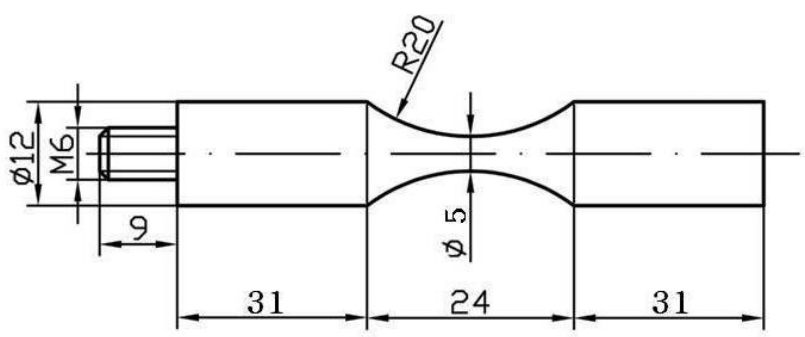

Fig. 2. Dimensions of specimen (dimensions in $\mathbf{m m}$ )

The geometry of presented equipment (Fig. 3) is optimised for the measurements at the resonant frequency fr about $20.5 \mathrm{kHz}$, but this is just one of many resonant frequencies which can be used by this equipment. The mass of ultrasonic resonance equipment (Fig. 4 and Fig. 5) is much bigger than the mass of the specimen. Ultrasound generator creates a sine wave. The electric signal is then amplified and transformed into mechanical wave by the piezoceramics transducer. 


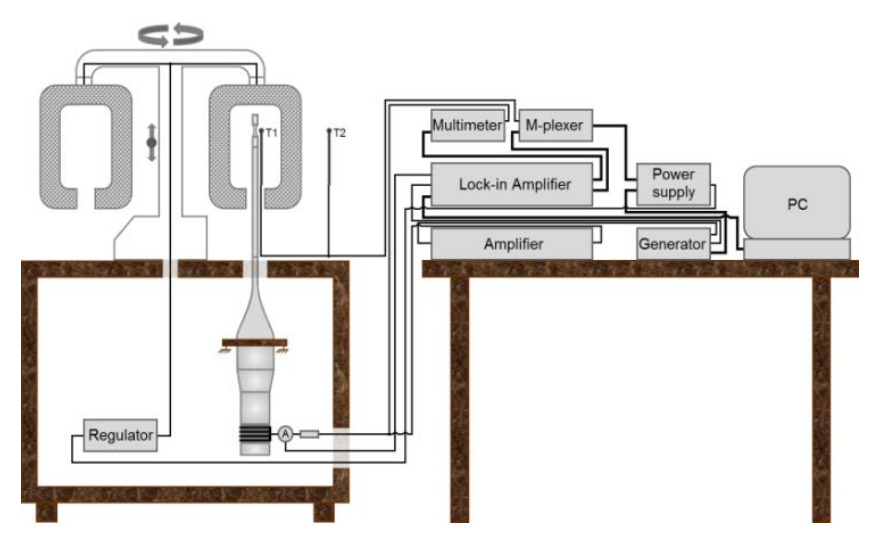

Fig. 3. Ultrasonic resonance device for internal friction measurement

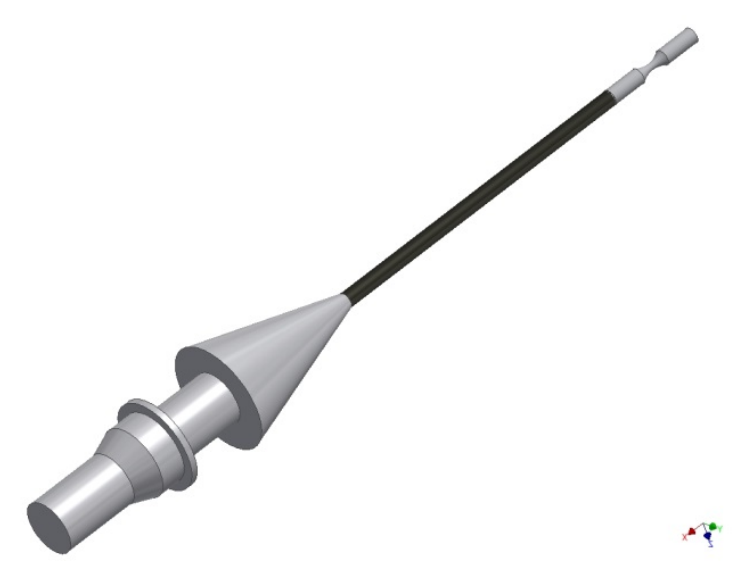

Fig. 4. Mechanical part of device

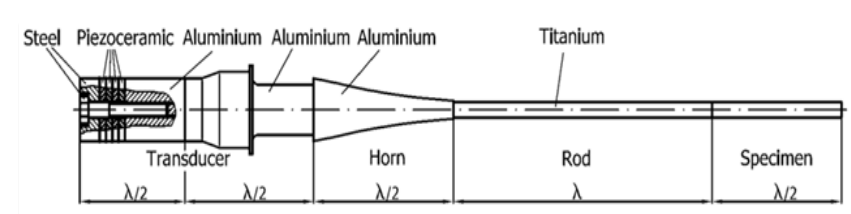

Fig. 5. Detailed description of mechanical part

The ultrasonic wave is concentrated in aluminium horn and spreads to the specimen through a titanium rod. After passing through the specimen the wave is reflected at the free end and spreads back through the entire apparatus until it is again reflected at the free end of a steel mirror, which is under the transducer. The amplitude of mechanical wave is decreasing during the propagation due to the internal friction of material. After the second reflection the mechanical wave interferes with itself. The standing wave is set up in the apparatus. The amplitude of resulting oscillations is measured by a multimeter because the current in pie- zoceramics transducer is proportional to the strain rate. (SOVIAROVÁ A., 2013b; PORUBČAN J., 2012).

\section{Experiment}

In experimental measurements only resonance methods were used. This method is based on continuous excitation of oscillations of the test bar, and the entire apparatus vibrates at a frequency which is close to the resonance.

Ultrasonic resonance systems can measure only at a single resonant frequency. Before the measurement is necessary to adjust the specimen so the resonance frequency of ultrasonic horn with mounted specimen is the same as resonance frequency of the ultrasonic horn by itself.

For the measurement of the decay test specimen it was designed so that the resonance frequency with resonance frequency mechanical part. For measurement specimens machined from EN AC 51200 alloy were used. Starting resonance frequency for all measurements was close to $\mathrm{f}=20470 \mathrm{~Hz}$.

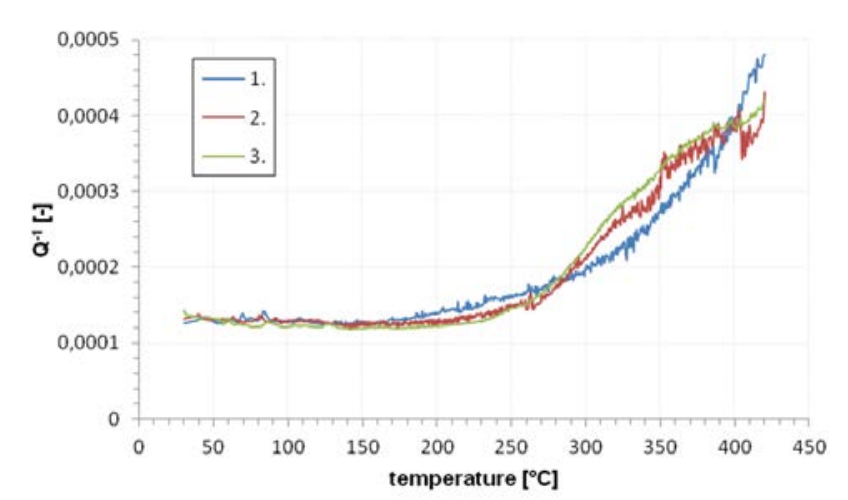

Fig. 6. Temperature depence on internal friction

In figure 6 it can be seen that our measured waveforms can also be divided into two periods. The first interval of temperature of $30^{\circ} \mathrm{C}$ to $170{ }^{\circ} \mathrm{C}$ and the second temperature interval from $170^{\circ} \mathrm{C}$ to $420^{\circ} \mathrm{C}$, which was the end of the measurement. During the measurement local maxims of quality factor occurred in a narrow temperature interval. Similar material changes were also studied in work (KASENČÁK M., 2010) and the presence of these maxims is still not clear so, there is still a discussion about the reason of 
their creation. According to previous studies (KASENČÁK M., 2010; NAMAŠNÝ A., 2008) the presence of local maxims depends on frequency, temperature and the deformation amplitude. Three dependencies measured in this interval were not identical and the differences are probably caused by external factors. These differences can be considered as unimportant when compared to differences measured in the second interval.

A local maxim was present from the temperature of $170{ }^{\circ} \mathrm{C}$. During the first measurement a small increase of the internal damping occurred at a temperature of $170{ }^{\circ} \mathrm{C}$ and then the temperature independent decrease of internal damping started at a temperature of $280^{\circ} \mathrm{C}$. In the second and third measurement from this temperature, the value of internal damping increased up to temperature of $400{ }^{\circ} \mathrm{C}$, and the character of the both curves was identical. The increase of internal damping at higher temperature is explained by various mechanisms, not only dissolution of alloying elements.

\section{Conclusion}

Based on experimental results from internal friction measurement of EN AC 51200 aluminium alloy can be stated:

- the internal damping increases with increasing of temperature,

- after several cycles of a specimens through temperature range from $30{ }^{\circ} \mathrm{C}$ to $400{ }^{\circ} \mathrm{C}$, the internal damping starts to decrease,

- decreasing of internal damping was probably caused by precipitation of intermetallic phases in the microstructure,

- microstructure state influences the values of internal damping and backwards, measurement of internal damping can be used to evaluate the microstructure state of material

\section{Acknowledgement}

This work has been supported by Scientific Grant Agency of Ministry of Education of Slovak Republic and Slovak Academy of Sciences, No1/0797/12.

\section{Literature}

1. BLANTER, M. (2007). Internal Friction in Metallic Materials, pp.539, Springer - Verlag: Berlin Heidelberg. ISBN 3-540-68757-2.

2. HLAVÁČOVÁ, I., PALČEK, P., CHALUPOVÁ, M., DRESSLEROVÁ, Z. (2013). Plastic deformation properties of Magnesium alloy AZ61, pp.313-319. Manufacturing Technology, Vol.13, Num.3, ISSN 1213-2489.

3. HURTALOVÁ, L., TILLOVÁ, E. (2013). Elimination of the negative effect of FE-rich intermetallic phases in secondary (recycled) aluminium cast alloy, pp.44-50. Manufacturing Technology, Vol.13, Num.1, ISSN 1213-2489.

4. KASENČÁK, M. (2010). Vnútorné tlmenie zliatin horčika $v$ závislosti od amplitúdy deformácie: Dizertačná práca, Žilina: Žilinská Univerzita v Žiline, 97 p.

5. NAMAŠNÝ, A. (2008). Štúdium vlastností horčikových zliatin meraním vnútorného tlmenia: Dizertačná práca, Žilina: Žilinská Univerzita v Žiline, 90 p.

6. PORUBČAN, J., PALČEK, P., BLAŽEK, D., TROJANOVÁ, Z. (2012). Internal friction in extruded aluminium alloy, pp.197-202. Solid State Phenomena: Internal friction and mechanical spectroscopy. Vol. 184, ISSN 1012-0394.

7. PUŠKÁR, A.(1995). Vnútorné tlmenie materiálov, pp.382, Žilina: EDIS, ISBN 80-7100-260-7.

8. SOVIAROVÁ, A., DRESSLEROVÁ, Z., PALČEK, P., CHALUPOVÁ, M.(2013a). Influence of precipitation on internal damping of AZ61 alloy. 30th international colloquium: Visegrád, Hungary - Budapešt', 2224 May 2013, pp.153-158. ISBN 978-963-313-079-7.

9. SOVIAROVÁ, A., PALČEK, P., BLAŽEK, D.(2013b), Analysis of Spurious Effects on Ultrasonic Internal Damping Testing Equipment, In TRANSCOM 2013 10th EUROPEAN CONFERENCE OF YOUNG RESEARCHES AND SCIENTISTS.

10. www.aalco.co.uk 